\title{
PENERAPAN BLENDED LEARNING DALAM RANGKA MEMPERSIAPKAN SEKOLAH DAN MASYARAKAT UNTUK TATANAN KEHIDUPAN BARU
}

\author{
*Suwarno1, Teguh Pramono², Ajie Hanif Muzaqi ${ }^{3}$ \\ 1, 2, 3 Program Studi Ilmu Administrasi Publik Fakultas Ilmu Sosial dan Ilmu Politik \\ Universitas Kadiri \\ *email : suwarno@unik-kediri.ac.id
}

\begin{abstract}
The COVID 19 pandemic has demanded that people adapt to a new normal life, including the education sector. This condition is a challenge for schools and the community. To avoid the widespread spread of the Covid-19 virus, schools must temporarily stop face-to-face learning activities. The blended learning method is a solution to these conditions. Blended learning activities are not only seen as a combination of online and face-to-face learning. However, this learning activity has a great opportunity to integrate innovation in educational technology and can be done online or face-to-face. Besides, blended learning is a solution to answering challenges in assembling learning and developing students' creativity. Even in the long term, blended learning is an important requirement for every school to face a brighter future. The implementation method in this program consists of the planning, implementation, and evaluation stages. The partners involved in this program are a team of IT experts at the Local Government of Kediri. Also, the partners involved are also active as speakers of educational technology. The results of this program are expected that teachers and schools can innovate in developing learning methods so that education in Indonesia will develop.
\end{abstract}

\section{Keywords: Blended Learning, School, Education}

\begin{abstract}
ABSTRAK
Pandemi Covid 19 memaksa masyarakat untuk beradaptasi dengan tatanan kehidupan yang baru tak terkecuali di dunia pendidikan. Kondisi ini menjadi tantangan tersendiri bagi sekolah, dan masyarakat. Guna menjaga dari semakin maraknya penyebaran virus Covid-19, sekolah terpaksa menghentikan kegiatan belajar tatap muka di kelas untuk sementara. Metode pembelajaran blended learning menjadi solusi di tengah kondisi seperti ini. Aktivitas pembelajaran blended learning bukan hanya dilihat sebagai kombinasi online dengan pembelajaran tatap muka saja. Namun aktivitas pembelajaran ini sangat berpeluang untuk mengintegrasikan inovasi di bidang teknologi pendidikan dan dapat di ajarkan secara online maupun tatap muka. Selain itu, blended learning juga sebagai solusi dalam menjawab tantangan dalam merangkai pembelajaran serta pengembangan kreativitas peserta didik, bahkan dalam jangka panjang pembelajaran berbasis blended learning menjadi kebutuhan penting bagi setiap sekolah guna menyongsong masa depan yang lebih cerah. Metode pelaksanaan dalam pengabdian ini terdiri dari tahap perencanaan, pelaksanaan, dan evaluasi. Mitra yang dilibatkan dalam pengabdian ini adalah tim tenaga ahli IT di Pemerintah Kota
\end{abstract}


Kediri. Selain itu mitra yang terlibat juga aktif sebagai pembicara di bidang teknologi pendidikan. Sedangkan sasaran dari pengabdian ini adalah guru dan Dinas Pendidikan. Hasil dari program ini diharapkan guru dan sekolah mampu berinovasi mengembangkan metode pembelajaran agar dunia pendidikan di Indonesia semakin berkembang.

\section{Kata Kunci: Blended Learning, Sekolah, Pendidikan}

\section{PENDAHULUAN}

Konsep new normal atau adaptasi kebiasan baru adalah perubahan pola sosial dan budaya seseorang dalam menjalankan aktivitas secara normal namun ditambah dengan penerapan protokol kesehatan yang tujuannya mencegah penularan Covid-19. (Bramasta, 2020). Dengan kata lain konsep new normal merupakan kehidupan normal baru, artinya aktivitas kehidupan yang kita jalani tetap normal namun dengan adaptasi menyesuaikan dengan keadaan yang baru. Adaptasi kehidupan yang baru berkaitan dengan penerapan protokol kesehatan seperti mencuci tangan, memakai masker, dan physical distancing. Hal tersebut akan diterapkan di segala aspek kehidupan di Indonesia termasuk dunia pendidikan.

Pandemi Covid-19 suka tidak suka telah "memaksa" seluruh komponen pendidikan di Indonesia untuk menerapkan pembelajaran jarak jauh (PJJ). Penerapan PJJ telah membawa sekolah dan dunia pendidikan terhadap konsep pembelajaran daring dan luring. Pemberlajaran daring secara istilah adalah peserta didik dan tenaga pendidik terkoneksi dalam sebuah jaringan yaitu internet (online). Sedangkan pembelajaran luring sama sekali tidak memanfaatkan jaringan internet (offline). Apabila sebelum pandemi pembelajaran di dalam kelas dilaksanakan dengan skema tatap namun dengan adanya pandemic berubah menjadi tatap maya dengan menggunakan teknologi seperti video conference atau web conference.

Memasuki era new normal pastinya pembelajaran juga kembali pada aktivitas normal seperti pembelajaran yang biasa berlangsung di sekolah. Kondisi tersebut tentunya perlu menerapkan sistem pembelajaran yang mendukung pembelajaran tatap muka langsung, pembelajaran daring, pembelajaran luring, namun tetap pada protokol kesehatan. Terdapat beberapa aspek pendidikan yang tentunya harus dipertimbangkan oleh pemerintah dalam penerapan kebiajakan new normal di dunia pendidikan. Sistem pembelajaran, kurikulum, kompetensi guru, serta infrastruktur sekolah pun harus disiapkan. Proses belajar mengajar di sekolah pun nantinya akan berbeda dengan sebelum masa pandemic. 
Blended learning dipandang dapat menjadi solusi di tengah situasi seperti ini. Selain itu, model pembelajaran ini dapat dijadikan solusi atas pesatnya perkembangan teknologi di dunia pendidikan. Aktivitas pembelajaran blended learning bukan hanya dilihat sebagai kombinas online dengan pembelajaran tatap muka saja. Namun aktivitas pembelajaran ini sangat berpeluang untuk mengintegrasikan inovasi di bidang teknologi pendidikan dan dapat di ajarkan secara online maupun tatap muka. Selain itu, blended learning juga sebagai solusi dalam menjawab tantangan dalam merangkai pembelajaran serta pengembangan kreativitas peserta didik (Thorne, 2003). Senada dengan pendapat Thorne, Dzuibal dkk (2018) juga menjelaskan bahwa blended learning telah mengkontruksikan dirinya dalam kondisi normal baru. Blended learning mampu beradaptasi dengan keadaan dan dapat dijadikan daya ungkit untuk peningkatan proses belajar mengajar dalam lingkungan pendidikan yang lebih resposif di tengah gaya hidup anak-anak kontemporer. Sedangkan Brian dan Volchenkova (2016) berpendapat bahwa teknologi inovasi di bidang pendidikan dapat memperlebar jangkauan solusi pembelajaran, menciptakan pengalaman belajar yang lebih efektif, meningkatkan akses dan fleksibiltas, atau dapat mengurangi ongkos belajar mengajar. Sistem pembelajaran blended learning merupakan gabungan antara proses belajar mengajar metode tatap muka serat belajar mengajar secara online yang arahnya meningkatkan efektifitas, akses, dan aksesibilitas dalam pengembangan potensi individu peserta didik.

Adapun pendapat Chaeruman dan Maudiarti (2018) menjelaskan terdapat 4 (empat) ruang belajar dalam aktivitas blended learning yang terdiri dari singkron secara langsung (live synchronous), singkron virtual (virtual synchronous), asinkron mandiri (self-paced asynchronous), serta asingkron kolaboratif (collaborative asynchronous). 


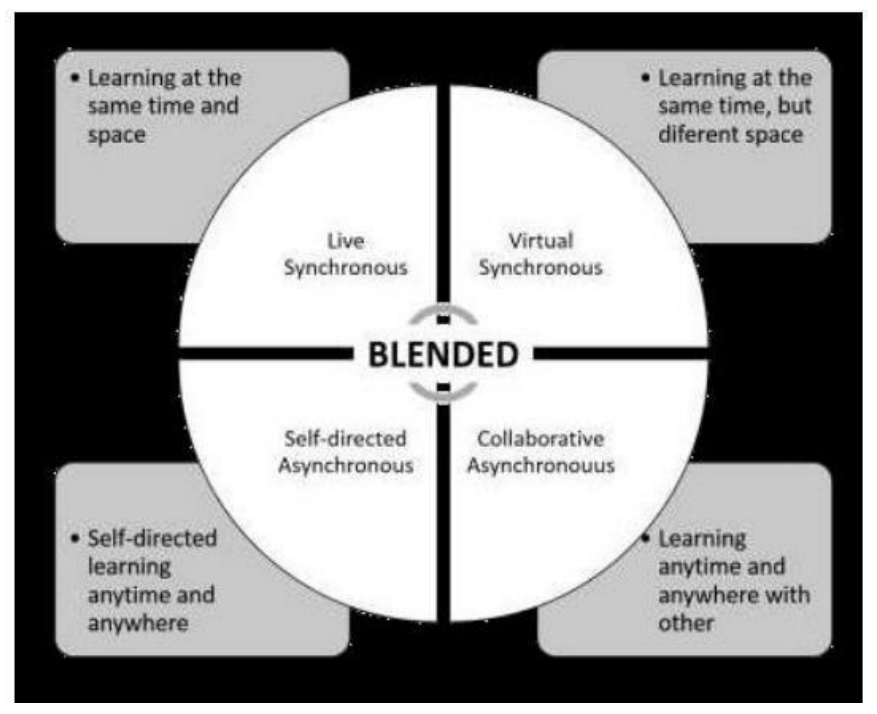

Gambar 1. Skema Blended Learning

Sumber : Chaeruman dan Maudiarti (2018)

Singkron langsung (live synchronous) adalah metode pembelajaran yang dapat dilakukan secara langsung dengan melakukan tatap muka di waktu dan tempat yang sama (real time). Pembelajaran tatap muka di kelas yang biasa dilakukan di sekolah dengan adanya interaksi tatap muka antara tenaga pendidik dan peserta didik secara langsung. Singkron virtual (virtual synchronous) adalah pembelajaran yang dilakukan secara langsung dengan tatap maya dalam waktu sama (real time) tetapi memiliki tempat berbeda. Pembelajaran secara tatap maya dengan menggunakan berbagai macam teknologi videon conference inilah sebagai sinkron virtual.

Sedangkan Asinkron mandiri (self-directed asynchronous) merupakan pembelajaran yang dilaksanakan secara mandiri kapanpun dan dimanapun. Peserta didik dapat mengambil inisiatif sendiri untuk menentukan kebutuhan dan tujuan belajar. Selain itu, asingkron mandiri dapat mengidentifikasi sumber belajar, memilih dan menerapkan strategi pembelajaran, serta mengevaluasi hasil pembelajaran. Pembelajaran ini dapat dilakukan dengan melihat, membaca, mendengar, dan memperhatikan learning object dalam berbagai jenis. Media dan alat yang dapat digunakan berupa video, televise, radio, ataupun podcast. Sementara itu, Asingkron kolaboratif (collaborative asynchronous) adalah sistem pembelajaran yang dilakukan dengan cara kolektif dengan orang lain kapanpun dan dimanapun. Pembelajaran seperti ini dilakukan dengan saling mengkritisi, mendiskusikan, mengevaluasi, membandingkan, serta meniliti yang difasilitasi oleh teknologi kolaboratif. Sebagai contoh bekerjasama dalam forum diskusi online, blog, lark, dan sebagainya. 
Di era pandemic ini dari 4 (empat) ruang belajar yang ada hanya ruang belajar singkron langsung (live synchronous) yang belum bisa diterapkan secara optimal. Proses pembelajaran yang telah berlangsung bisa menggunakan ketiga ruang belajar lainnya (Chaeruman, 2020). Ketiga ruang belajar tersebut (sinkron virtual, asinkron mandiri, dan singkron kolaboratif) sudah menjadi habit di lingkungan sekolah, guru, siswa, dan orang tua. Unsur-unsur tersebut sudah menjadi roh dalam proses pembelajaran yang dilakukan pada era pandemic ini.

Pembelajaran yang dilaksanakan pada masa "new normal” ini pastinya dapat berbeda dengan aktivitas belajar mengajar seperti biasanya. Kebijakan terkait peraturan dan kurikulum perlu disiapkan oleh pemerintah. Pemerintah juga turut mengkaji kesiapan sekolah dan guru dalam melaksanakan proses belajar mengajar yang nantinya dilaksanakan. Sekolah harus siap dengan infrastruktur dan manajemen yang dibutuhkan dalam proses belajar mengajar. Begitu juga dengan tenaga pengajar harus dapat meningkatkan kompetensi dalam penguasaan berbagai macam model, metode, dan strategi pembelajaran yang kreatif dan inovatif. Outcome yang diharapkan tentunya dapat meningkatkan prestasi belajar siswa dan keselamatan dalam menjalani proses belajar mengajar

\section{METODE PELAKSANAAN}

Metode dalam kegiatan pengabdian ini dilaksanakan dengan 3 (tiga) tahap yaitu perencanaan, pelaksanaan, dan evaluasi. Perencanaan dilakukan melalui diskusi serta komunikasi intens dengan mitra. Salah satu kegiatan yang dilakukan adalah menyusun jadwal pelatihan dengan mitra dengan melibatkan guru pada jenjang SD dan SMP. Mitra yang dilibatkan dalam pengabdian ini adalah salah satu guru SMP Negeri 2 Kediri dimana mitra tersebut merupakan tim tenaga ahli IT di Pemerintah Kota Kediri. Selain itu mitra yang terlibat juga aktif sebagai pembicara di bidang teknologi pendidikan

Pelaksanaan kegiatan dalam program pengabdian ini meliputi pelatihan penggunaan media pembelajaran daring yang meliputi google classroom, google meet, sampai aplikasi Ujian Berbasis Komputer Dalam Jaringan (UBKD). Partisipasi mitra dalam program ini adalah sebagai fasilitator pelaksanaan kegiatan serta tempat kegiatan. Kedepannya tidak menutup kemungkinan untuk guru-guru yang ada di wilayah Kabupaten Kediri dapat bergabung pada acara pelatihan dan penyuluhan program ini. 
Selanjutnya, evaluasi dalam program pengabdian ini dilaksanakan secara periodik setelah kegiatan berlangsung. Kegiatan tersebut nantinya dapat dilihat perkembangannya serta ditindaklanjuti melalui grup social media. Kedepannya akan dilakukan monitoring aplikasi apa saja yang dimanfaatkan dalam proses belajar mengajar di kelas masing-masing. Hal tersebut tentunya dapat dijadikan kontribusi bagi keberlanjutan program lain yang sejenis. Salah satu kegiatan evaluasi yang dilakukan adalah assessment dimana bagaimana membuat assessment berbasis elektronik, sehingga kerjasama ini dapat terus berlangsung. Di samping itu, evaluasi dari peserta didik juga dapat dilihat dari nilai akademik siswa. Apakah ada perkembangan nilai menggunakan metode blended learning.

\section{HASIL DAN PEMBAHASAN}

Konsep blended learning adalah bukan lagi berdasarkan mata pelajaran maupun berdasarkan penguasaan konten atau materi tetapi ini berdasarkan kompetensi minimum yang dibutuhkan siswa untuk bisa belajar apa pun mata pelajarannya. Blended learning terdiri dari kemampuan bernalar menggunakan bahasa (literasi), kemampuan bernalar menggunakan matematika (numerasi), dan penguatan pendidikan karakter. Selain itu, dilakukan pula survey karakter di akhir pengajaran tujuannya untuk mengetahui data secara nasional mengenai penerapan asas-asa Pancasila oleh peserta didik Indonesia.

Pelatihan beserta simulasi penggunaan media pembelajaran berbasis daring memiliki tujaun diantarnya 1) memperkenalkan kepada sekolah (Kepala Sekolah, Guru, dan Siswa) dan Dinas Pendidikan di Kota Kediri tentang konsep blended learning khususnya materi dan model/ tipe soal, 2) Membiasakan kepada siswa akan adanya proses pembelajaran berbasis IT termasuk metode ujian akhir dengan menggunakan CAT (computer assessment test), 3) Menginformasikan kepada sekolah tentang infrastruktur penunjang dalam mendukung proses belajar mengajar, 4) Meningkatkan kreativitas siswa dan guru, 5) Meningkatkan pemahaman terhadap aplikasi belajar mengajar, 6) Meningkatkan pengalaman dalam pembelajaran berbasis elektronik, 7) Meningkatkan penguasaan terhadap infrastruktur sistem dan 8) Memberikan parameter baru tentang proses belajar mengajar.

Sementara itu tugas utama dari pendamping (peneliti dan mitra) adalah sebagai berikut. 1) Memastikan sarana dan prasarana sesuai spesifikasi minimum sistem aplikasi, 2) Memastikan data yang di imput peserta sudah sesuai, 3) Membantu menyelesaikan permasalahan teknis dan non teknis pelaksanaan pembelajaran daring di instansi masing- 
masing, 3) Bertanggungjawab terhadap kelancaran pelaksanaan daring, 4) Menghimpun segala macam permasalahan yang terjadi dilapangan untuk di tindaklanjuti oleh Pemerintah Kota.

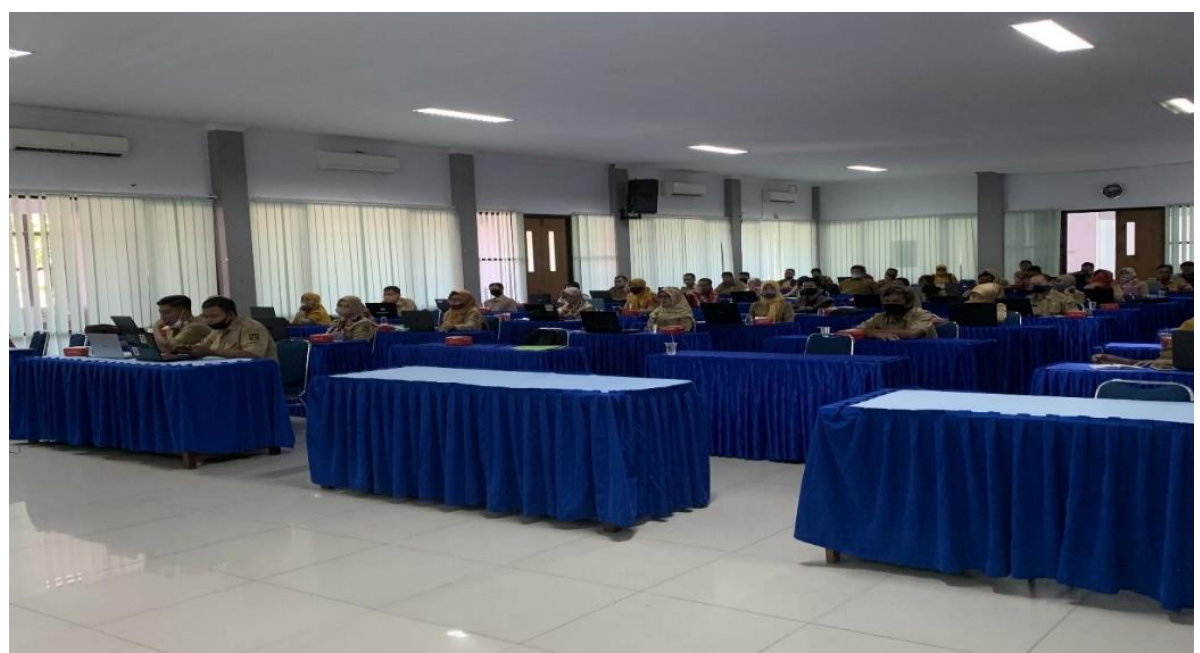

Gambar 2. Dokumentasi saat pelatihan sistem e-learning

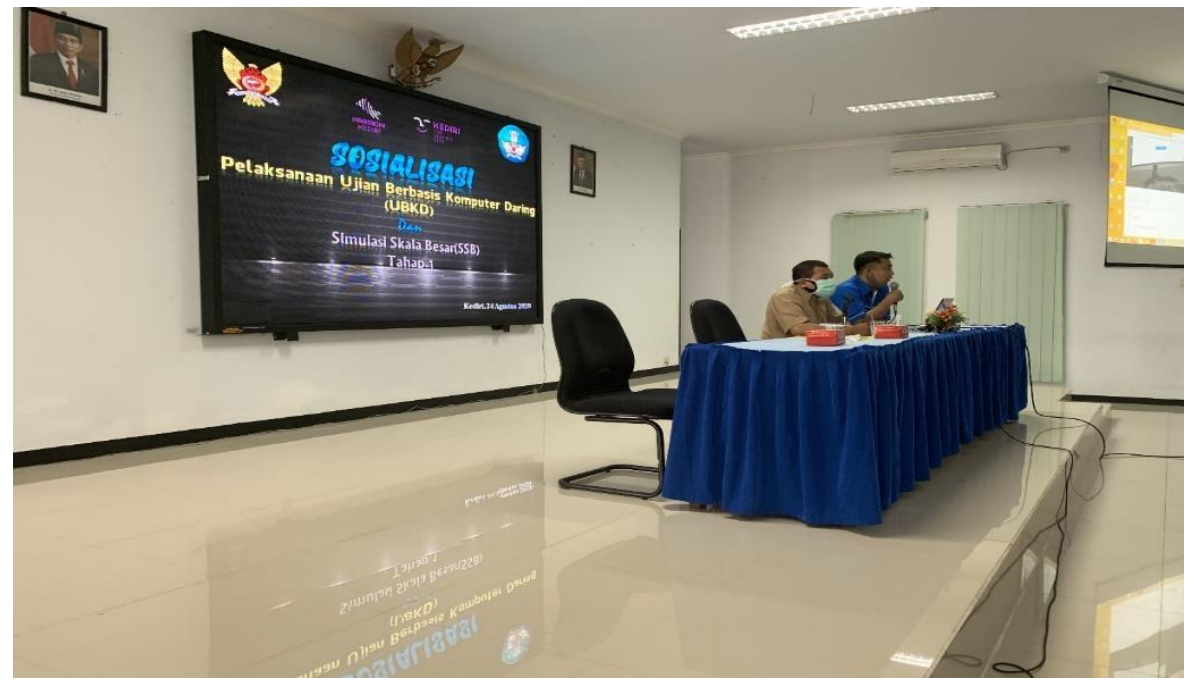

\section{Gambar 3. Sosialisasi tentang pelaksanaan ujian berbasis computer daring}

Respon para peserta dalam pelatihan ini sangatlah positif. Para peserta yang terdiri dari guru SD dan SMP di Kota Kediri berpendapat bahwa penggunaan aplikasi daring dalam pembelajaran sangat bermanfaat kedepannya. Guru yang mengikuti pelatihan ini diharapkan dapat menjadi agen perubahan di instansi masing-masing. Di samping itu juga memberi manfaat bagi siswa yang terpaksa harus belajar dari rumah karena situasi pandemic seperti ini. Oleh sebab itu, adanya kegiatan ini diharapkan dapat memberi motivasi guru-guru untuk 
lebih kreatif dalam pemanfaatan teknologi untuk menunjang keberhasilan proses belajar mengajar. Kemudian dapat memudahkan sistematika dalam pelaporan kegiatan.

Adapun proses pelaksanaan pelatihan ini diawali dari pengkondisian para peserta (guru) dengan menggunakan media seperti laptop. Setelah itu, mitra dan penulis mulai memaparkan jenis-jenis aplikasi pembelajaran daring sebagai instrument untuk mendukung proses belajar mengajar. Dalam hal ini para pengajar berkolaborasi dalam menggunakan aplikasi tersebut. Beberapa guru bahkan langsung menerapkannya dengan melakukan video conference dengan kelas masing-masing. Guru dan siswa dapat langsung terkoneksi dan saling berkomunikasi meski dipisahkan oleh jarak dan waktu. Dalam praktiknya beberapa guru menanyakan beberapa fitur untuk mengetahui fungsinya. Kondisi tersebut menunjukan bahwa peserta pelatihan cukup tertarik akan kegiatan ini

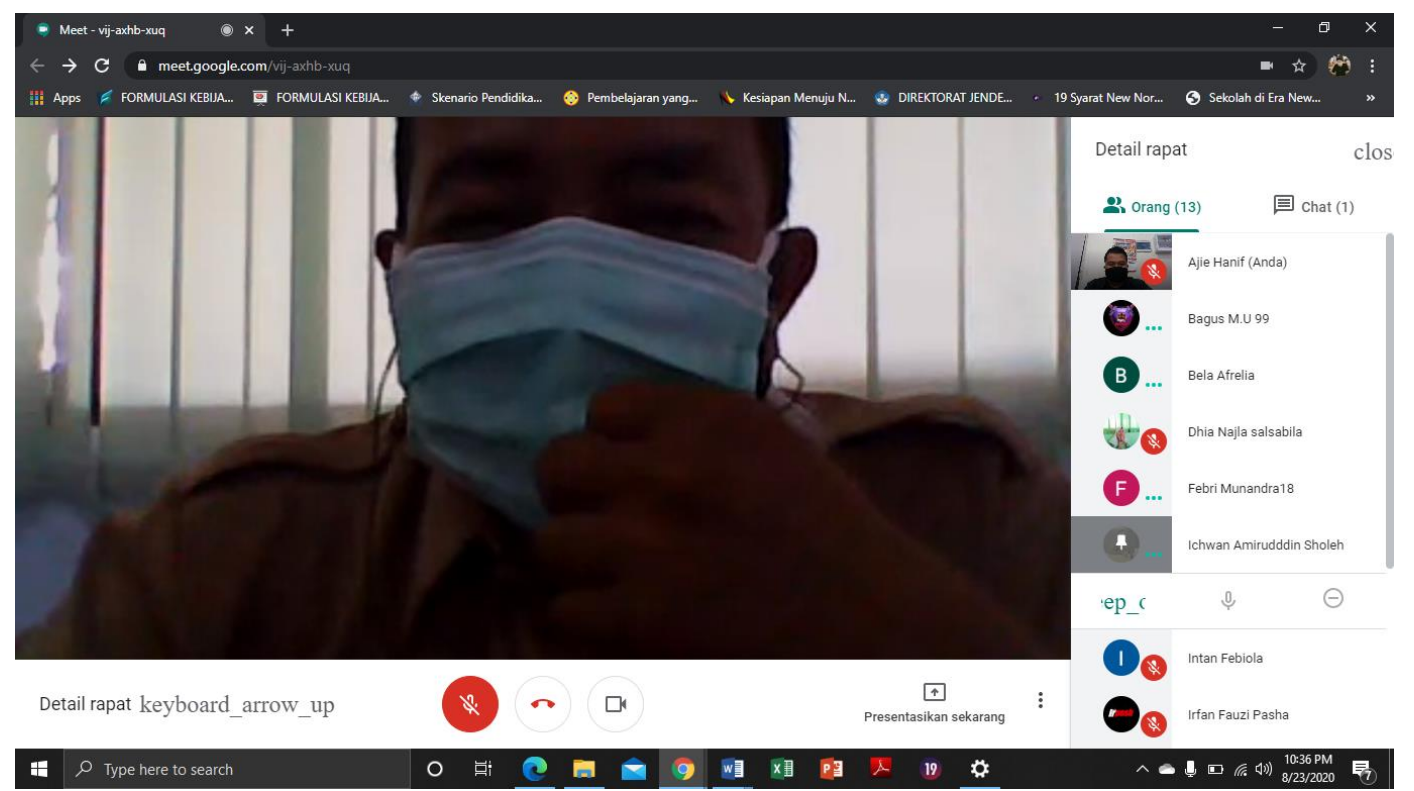

Gambar 4. Simulasi langsung penggunaan aplikasi Google Meet

Berikutnya dilakukan pula simulasi belajar mengajar dengan menggunakan aplikasi google classroom. Tujuannya ialah memperkenalkan metode pembelajaran selain video conference sebab pada praktiknya proses belajar mengajar bukan hanya guru menerangkan kepada siswa namun diperlukan pula aktivitas seperti diskusi kelompok dan Pekerjaan Rumah (PR). Melalui aplikasi seperti google classroom di harapkan keaktivan siswa dapat terlihat dan di record dengan baik. 

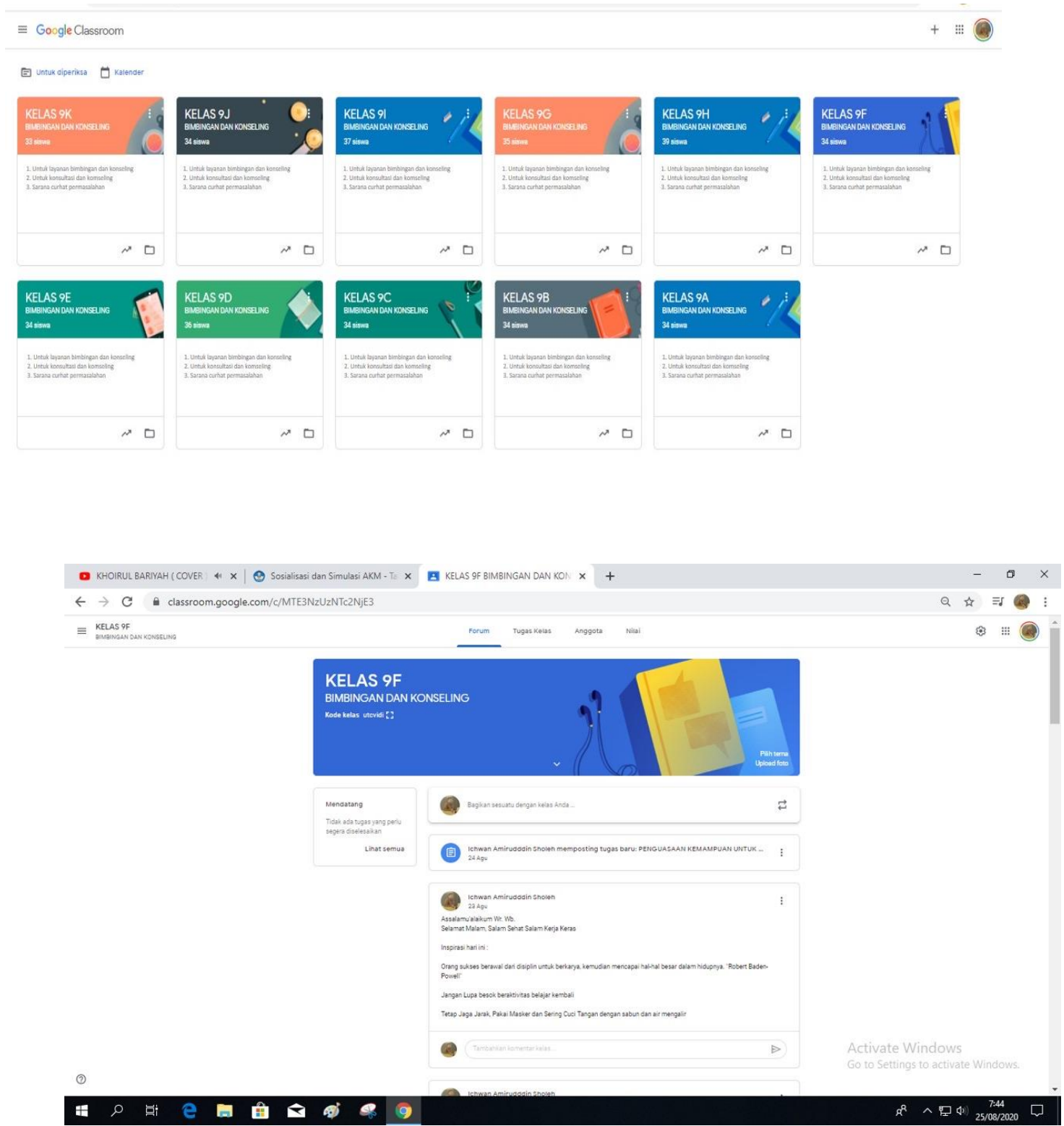

Gambar 5. Tampilan Laman Awal Google Classroom

Di akhir sesi, pemateri penyampaikan tentang konsep assessment kompetensi pengganti Ujian Nasional. Hal tersebut sesuai dengan arahan Presider RI bahwa untuk meningkatkan kualitas sumber daya manusia (SDM) diperlukan ujian baik sekolah maupun nasional yang lebih jujur dan sesuai kemampuan. Selain itu, Peraturan Menteri Pendidikan dan Kebudayaan Republik Indonesia Nomor 43 Tahun 2019 Tentang Penyelenggaraan Ujian yang Diselenggarakan Satuan Pendidikan dan Ujian Nasional, tertanggal 10 Desember 2020. Salah satu poin penting dari dua kebijakan tersebut diatas bahwa Ujian Nasional (UN) tahun 
2020 merupakan UN terakhir yang akan diselenggarakan dalam sejarah pendidikan Indonesia. Dilihat dari kondisi tersebut maka, aplikasi Ujian Berbasis Komputer Dalam Jaringan (UBKD) menjadi hal yang wajib dikuasai oleh guru dan siswa guna menunjang pendidikan di Indonesia.

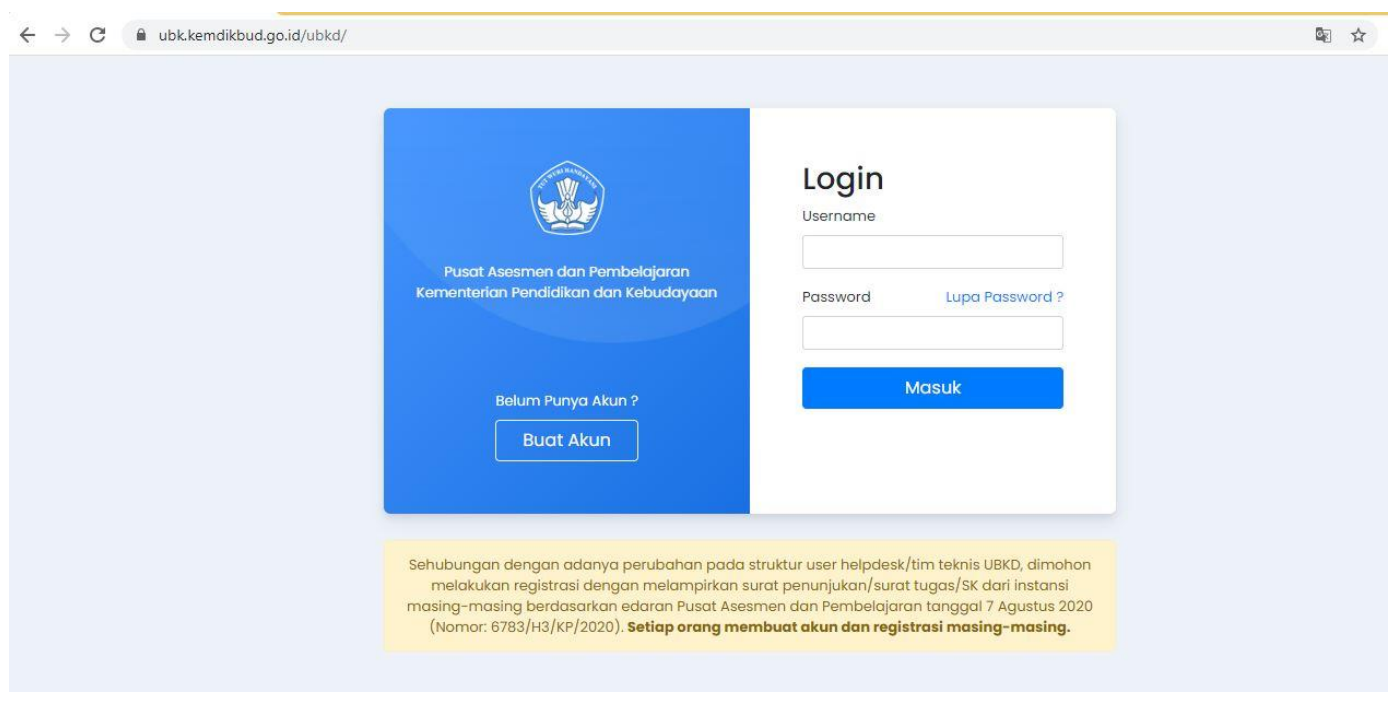

\section{Gambar 5. Tampilan Laman UBKD}

Setelah dilakukan pelatihan beserta simulasi penggunaan aplikasi belajar mengajar daring maka hal yang dapat dijadikan evaluasi dan perhatian adalah adanya keterbatasan koneksi internet yang sangat mendukung pembelajaran berlangsung ketika hal itu terpenuhi dengan baik. Kemudian adalah kemampuan guru dalam menyiapkan bahan ajar, sebab dengan menggunakan aplikasi seperti google classroom perencanaan studi menjadi kunci utama optimalnya aplikasi ini. Guru tidak lagi bisa berimprovisasi layaknya belajar mengajar dengan cara tatap muka langsung. Maka hal itu menjadi tantangan tersendiri untuk pengajar yang bisa menstimulasi peserta didik untuk mendukung strategi belajarnya. Selain itu, terdapat pula peserta didik yang menggunakan peralatan seperti laptop yang tidak sesuai dengan spesifikasi khusus. Sehingga beberapa aplikasi pembelajaran tidak mampu di jalankan secara optimal.

\section{DAFTAR PUSTAKA}

Bramasta, Dandy Bayu. (2020). "Mengenal Apa Itu New Normal di Tengah Pandemi Corona.". Harian Kompas. Diakses tanggal 3 Agustus 2020 
Brian, A., and K.N. Volchenkova. (2016). Blended Learning: Definition, Models, Implication for Higher Education. Bulletin of the South Ural State University. Ser. Education. Educational Sciences. vol. 8, no. 2, pp. 24-30.

Chaeruman, Uwes A. (2020). Tips Implementasi Flipped Learning. Materi disajikan dalam Webinar APSTPI 2020.

Chaeruman, Uwes A. dan Santi Maudiarti. (2018). Quadrant of Blended Learning: $a$ Proposed Conceptual Model for Designing Effective Blended Learning. Jurnal Pembelajaran Inovatif1(1) (2018): 1-5.

Dziubal, Charles., et.al. (2018). "Blended learning: the new normal and emerging technologies. International Journal of Educational Technology in Higher Education volume 15, Article number: 3.

Thorne, K. (2003). Blended Learning: “How to Integrate Online and Traditional Learning”. London, UK: Kogan Page Limited. 